\title{
Structural and Thermal Changes in Dental Resins Enriched with Silver Nanoparticles
}

\author{
ANCA VITALARIU ${ }^{1}$, MONICA TATARCIUC ${ }^{1 *}$, ODETTE LUCA ${ }^{1}$, CATALINA HOLBAN CIOLOCA ${ }^{1}$, BO GDAN BULANCEA ${ }^{1}$, \\ ANDRA AUNGURENCEI ${ }^{1}$, OVIDIU AUNGURENCEI ${ }^{1}$, GHEORGHE RAFTU², DIANA DIACONU POPA ${ }^{1}$ \\ ${ }^{1}$ University of Medicine and Pharmacy GrigoreT.Popa Iasi, Faculty of Dental Medicine, Departament of Implantology, Removable \\ Prosthesis, Dental Technology, 16 Universitatii Str., 700115, Iasi, Romania \\ 'University Ovidius of Constanta, Counselling and Career Guidance Centre, 124 Mamaia Blvd., 900527, Constanta, Romania
}

\begin{abstract}
Acrylic resins are frequently used in dentistry for the removable partial or complete denture but, epidemiological studies report that approximately $70 \%$ of removable denture wearers suffer from denture stomatitis. Silver nanoparticles (AgNps) incorporation aims to avoid or at least to decrease the microbial colonization over dental materials, but their influence on the mechanical features is still not very well known. A total of 100 heat curing and 100 of self-curing acrylic resin samples were made, and divided into three groups for both resins (ten for each), according to the concentration of AgNPs solution (5\%, 10\%, and $20 \%$ vol.) incorporated into the monomer. One control group without AgNPs for each resin was prepared, as well. The dimensions of the used AgNPs, were 20, 40 and $60 \mathrm{~nm}$. The structural changes were analyzed with Scanning Electron Microscopy (SEM) and Atomic Force Microscopy (AFM). The thermal behavior was evaluated through Differential Scanning Calorimetry (DSC). The results demonstrated that AgNPs incorporation doesn't induce significant structural and thermal changes in dental resins.
\end{abstract}

Keywords: acrylic resins, silver nanoparticles, structural analysis, thermal analysis

The exceptional broad antimicrobial spectrum of Silver has been known and used for hundreds of years. Silver Nanoparticles (Ag NPs) are clusters of silver atoms that range in diameter from 1 to $100 \mathrm{~nm}$. Due to their antibacterial, antifungal, antiviral, and anti-inflammatory activity, AgNPsprovide one of the most cost effective antibacterial agents for various applications: textiles, renewable energy, environment, electronics, food/ agriculture, health care and biomedical $[1,2]$.

Their unique chemical and physical properties and pronounced antibacterial activity, provide one of the most cost effective antibacterial agents for applications in MEDICINE for: diagnosis, treatment, dug delivery, bone cements, cardiovascular implants, medical device coating, wound dressings, medical textiles, contraceptive devices, etc.

Induction of antimicrobial activity in dental materials has been widely a large concern in dentistry, their usefulness being proved in Orthodontic adhesives, Dental instruments, Endodonticsfilling materials and Prosthodontics [3-6].

Despite the continuous progress in material science, Polymethyl Methacrylate (PMMA) is still the most used material for denture bases. A common problem faced by the acrylic denture wearers is the denture stomatitis, which is related to the specific conditions of the oral cavity, the state of the patient's immune system, butalso to the PMMA surface characteristics, that facilitates the bacterial-fungal biofilm formation. The classic treatment for denture stomatitis is based on topical or systemic antifungal drugs, but this infection is often persistent, since antifungal resistance has been reported in Candida Albicans biofilm [ 7 - 13]. So, the prophylaxis of dental stomatitis by AgNPs incorporation represent a challenge. The antimicrobial effect of AgNPs was demonstrated to be directly proportional to the concentration and inversely proportional to their diameter. Normally, a high concentration leads to more effective antimicrobial activity, while particles of small size can kill bacteria at a lower concentration. Particles larger than $100 \mathrm{~nm}$ showed only a bacteriostatic activity, while smaller particles have bactericidal effect. The smaller the particles $(I<10 \mathrm{~nm})$, the greater the antimicrobial effect (because they can penetrate into the bacteria, not only on it's surface).

Our aim was to evaluate the structural changes and the thermal behavior of the composite material resulted after AgNPs incorporation into acrylic dental resins.

\section{Experimental part}

\section{Materials and methods}

Specimens preparation

In order to obtain the samples we used two different types of acrylic dental resins: a heat curing (Futura Basic Heat /Schutz Dental/Germany) and a self-curing resin (Futura Basic Cold/Schutz Dental/Germany)

Colloidal silver nanoparticles (AgNps) 20,40 and $60 \mathrm{~nm}$ ( $0.02 \mathrm{mg} / \mathrm{mL}$ Sigma Aldrich/USA) as 5, 10, 20\% volume concentration were incorporated in the two type of acrylic resins. We considered relevant to analyze different dimensions and concentrations because the antimicrobial activity of AgNps is influenced by the dimension and concentration of the particles (fig.1).

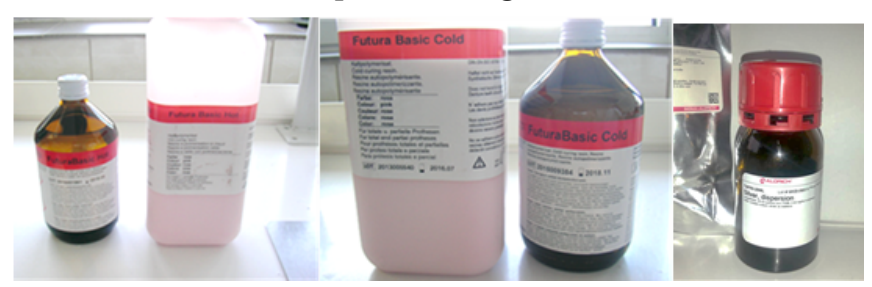

Fig.1. Acrylic resins Silver nanoparticles

We made 200 samples, and for each material were prepared 10 specimens as control and 30 test specimens, 30 for each dimension and concentration studied.

Pink wax patterns were made, $2 \mathrm{~mm}$ thickness, with $75 \mathrm{~mm}$ length, $12.5 \mathrm{~mm}$ width at the extremities and 4 $\mathrm{mm}$ in thickness in the central area. 
The wax patterns were transformed in acrylic specimens according to the technology used for acrylic dentures. They were invested in dental stone (Elite Rock class IV/Zhermack) in order to obtain a mold and then the acrylic resin pastes wereprepared, following the producers indications for each type.For Futura Basic Hot the polymer/ monomer mixing ratio was 2.5:1, and for Futura Basic Cold 10:7. The AgNps in the form of colloidal solution was added to the monomer of acrylic resin by volume proportion in 5 , 10 and $20 \%$ concentration and 20,40,60 nm diameter, excepting the control group specimens. The powder and liquid were mixed into a porcelain jar, then the acrylic resin paste was packed into the mold at the dough stage, theflask was closed and pressed. For the Futura Basic Hot the flask was immersed into a water bath and the temperature was rise up to $100^{\circ} \mathrm{C}$, at 2-4 bar, during 20 minutes, and for Futura Basic Cold reaction conditions havebeen $45^{\circ} \mathrm{C}, 2-4$ bar, during $5 \mathrm{~min}$. After polymerization the samples were finished with fine carbide burs, polished to a smooth and glossy surface, and finally immersed in distilled water and stored at $37^{\circ} \mathrm{C}$, for one week, before testing (fig.2).

\section{Structural Analysis}

Scanning electron microscopy (SEM)

To highlight possible changes in surface threedimensional morphology caused by AgNps addition, high resolution scanning electron microscopy (SEM) were performed. SEM analysis is the appropriate method to investigate microstructural changes occurring in resins after AgNPs incorporation. SEM produces images of a sample by scanning the surface with a focused beam of electrons that interact with atoms in the sample, producing various signals that contain information about the sample's surface topography and composition. Due to the very narrow electron beam, SEM micrographs have a large depth of field yielding a characteristic three-dimensional appearance useful for understanding the surface structure of the sample.

\section{Atomic force microscopy (AFM)}

An AFM depicts the topography of a sample surface by scanning a cantilever with a sharp tip over a region of interest. Attractive force betw een the surface and the tip causes the cantilever to deflect towards the surface. A laser beam is used to detect cantilever deflections towards or away from the surface.

In this paper, the structural analysis by using AFM wants to reveal - on submicronic and even nanometric scale the AgNps integration into resin matrix by surface topography.
To achieve the goal, prepared samples were examined using a NanosurfeasyScan 2 FlexAFM having a scan head capable of a maximum scanning range of $1 \mathrm{~mm}$.

3D topography and 2D deflection over the scanning range and along a control line were obtained.

To get an overall depiction of the nominated dental acrylic resins enriched with AgNps, a HCR's micron size analysis surface having $8 \mathrm{~mm}$ scanning range was initially chosen for structural analysis.

\section{Thermal analysis}

Thermal characterization of the modified resins was performed by Differential Scanning Calorimetry (DSC) giving valuable information on possible induced transformations up to $65^{\circ} \mathrm{C}$.

DCS is the most frequently used method in the field of Thermal Analysis, being used to determine transition temperatures and enthalpy changes in solids and liquids. Our purpose was to determine possible glass transition, decomposition and solid-solid transition. Thermograms over 20-60C with typical temperature rate of $10 \mathrm{~K} / \mathrm{min}$ were achieved by using the Netzsch DSC 200 F3 Maia. This device has two pans: the sample pan with the polymer sample, and the reference pan (empty). Each pan sits on top of a heater. The computer turns on the heaters, and heat the two pans at a specific rate, usually something like $10^{\circ} \mathrm{C}$ per minute. The heater underneath the sample pan has to work harder than the heater underneath the reference pan. It has to put out more heat. By measuring just how much more heat it has to put out is what we measure in a DSC experiment.

\section{Surface roughness}

Roughness is an important characteristic of surface quality and can be assessed by determining the micrometric profile of the finished and polished samples.The shape and dimensions of the micrometric profile have an influence on the adherence and development of the bacterial biofilm at the internal surfaces of the acrylic prostheses.

For each sample we calculated Rawhich represents the arithmetical mean of the absolute values of the profile deviations from the mean line of the roughness, and Rzthe average of all values represented by the maximum height between the maximum and the minimum profile within the assessment length, for each sample.

\section{Results and discussions}

The SEM images showed a homogenous dispersion of AgNPs into the organic matrix,without any dehiscence at the resin-nanoparticle interface (fig.3).
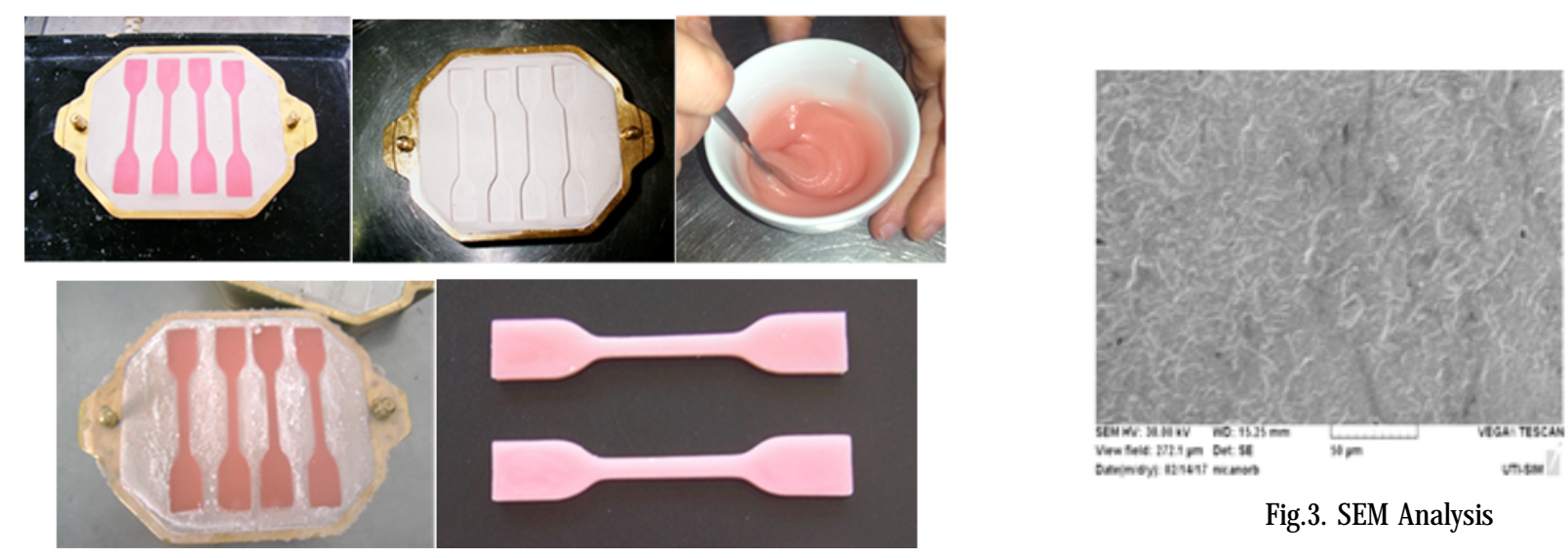

Fig.3. SEM Analysis

Fig.2. The specimen's preparation 

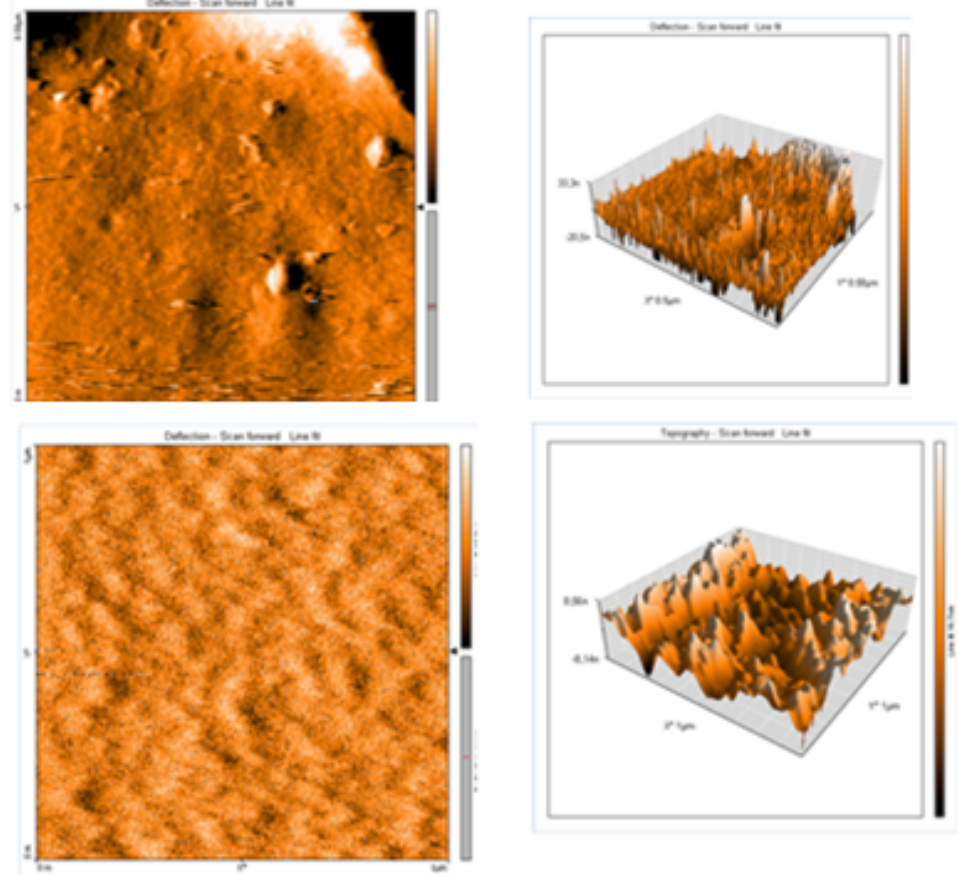

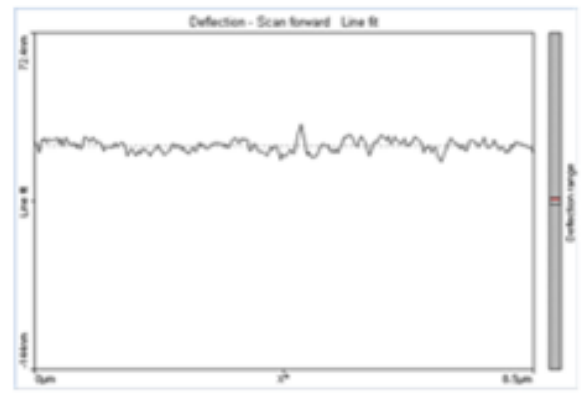

Fig.4. The AFM for HCR Analysis

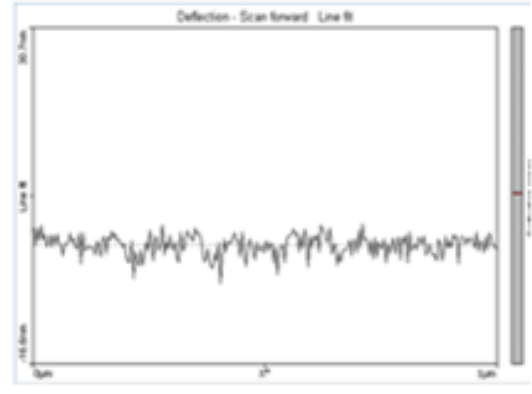

Fig. 5 The AFM for SCR
To get an overall depiction of the nominated dental acrylic resins enriched with AgNPs, a HCR's micron size analysis surface having $8 \mu \mathrm{m}$ scanning range was initially chosen for structural analysis through AFM. For $8 \mu \mathrm{m}$ size analysis surface of HCR there are no steps or cleavage on the relief of the sample, revealing an homogenous surface. The $2 \mathrm{D}$ deflection along the selection line shows a dimensional homogeneity. The vertical deviation of the roughness profile from the mean line is in range of +33.3 $\mathrm{nm} \ldots . .20 .5 \mathrm{~nm}$ (the profile has $8.5 \mu \mathrm{m}$ ) (fig.4).

Similarly, for a detailed analysis, a SCR's micron size analysis surface having only lum scanning range was nominated for submicronic analysis. Even for the smallest area of analysis that device can scan, a homogenous surface profile is registered. Again, the 2D deflection along the selection line shows a surprising dimensional homogeneity. The vertical deviations of the roughness profile from the mean line is in range of $+8.56 \mathrm{~nm}$...-8.14 nm (fig. 5).

Differential Scanning Calorimetry (DSC) determines transition temperatures and enthalpy changes in solids and liquids being the most frequently used method in the field of Thermal Analysis. Thermograms achieved over $20-60^{\circ} \mathrm{C}$ with typical temperature rate of $10 \mathrm{~K} / \mathrm{min}$ reveal no glass transition, decomposition or solid-solid transition by adding AgNPS both in SCR and HCR samples. No significant phase transformation in dental acrylic resins or AgNPs de-bonding were reported, in other words, adding of AgNPs doesn't affect the cross-linking system of resins (fig.6).

The roughness diagrams were recorded with the MahrPerthometer M1 (fig.7).

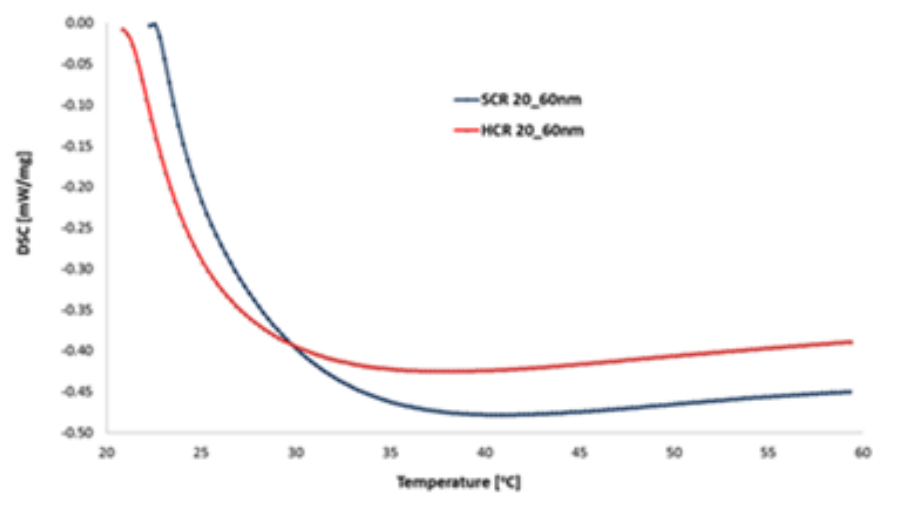

Fig. 6. Thermogram
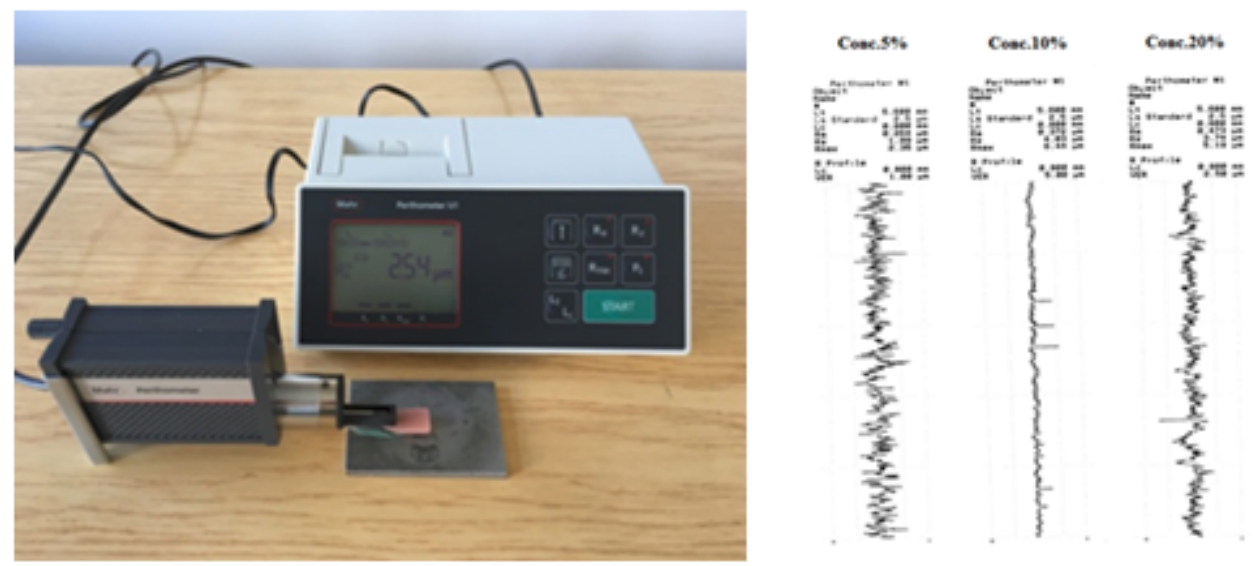

Fig.7.The roughness diagrams 


\begin{tabular}{|c|c|c|c|c|c|c|c|c|}
\hline \multicolumn{9}{|c|}{ Heat curing resin } \\
\hline & \multicolumn{2}{|c|}{$0 \mathrm{~nm}$} & \multicolumn{2}{c|}{$29 \mathrm{~nm}$} & \multicolumn{2}{c|}{$40 \mathrm{~nm}$} & \multicolumn{2}{c|}{$60 \mathrm{~nm}$} \\
\hline \hline & $\mathrm{Ra}$ & $\mathrm{Rz}$ & $\mathrm{Ra}$ & $\mathrm{Rz}$ & $\mathrm{Ra}$ & $\mathrm{Rz}$ & $\mathrm{Ra}$ & $\mathrm{Rz}$ \\
\hline $\mathbf{5}$ & 1.983 & 11.5 & & & & & & \\
\hline $10 \%$ & & & 0.248 & 2.51 & 0.225 & 1.74 & 0.202 & 1.33 \\
\hline $\mathbf{2 0} \%$ & & & 0,25 & 2.1 & 0.209 & 1.69 & 0.228 & 2.06 \\
\hline
\end{tabular}

Table 1

\begin{tabular}{|c|c|c|c|c|c|c|c|c|}
\hline \multicolumn{9}{|c|}{ Self curing resin } \\
\hline & \multicolumn{2}{|c|}{$0 \mathrm{~nm}$} & \multicolumn{2}{c|}{$29 \mathrm{~nm}$} & \multicolumn{2}{c|}{$40 \mathrm{~nm}$} & \multicolumn{2}{c|}{$60 \mathrm{~nm}$} \\
\hline \hline & $\mathrm{Ra}$ & $\mathrm{Rz}$ & $\mathrm{Ra}$ & $\mathrm{Rz}$ & $\mathrm{Ra}$ & $\mathrm{Rz}$ & $\mathrm{Ra}$ & $\mathrm{Rz}$ \\
\hline $\mathbf{5}$ & 3.374 & 16.3 & & & & & & \\
\hline $10 \%$ & & & 0.302 & 2.07 & 0.264 & 1.99 & 0.375 & 1.33 \\
\hline $\mathbf{2 0 \%}$ & & & 0,389 & 4.02 & 0.372 & 4.03 & 0.57 & 2.06 \\
\hline
\end{tabular}

The results showedno changes in the roughness of the heat curing and self-curing acrylic resin surfaces AgNps, compared to control samples (tables 1,2).

There are many articles in the literature about the effects ofAgNPs incorporation in denture resins on their mechanical, thermal, and structural properties. Their results and conclusions varied largely due to the differences in methodology, resin type, concentration and particle's size used[14-20]. Concerning the mechanical properties, there are studies that demonstrated that the AgNPs presence can improve some properties (viscoelastic properties, thermal conductivity, compressive strength) but in high concentrationresult in agglomeration sites, decreasing other mechanical properties of resin (tensile and strength)[7,21-28]. The results of our study on the structural changes and the thermal behavior of the dental acrylics with AgNps incorporated showed structural homogeneity and no modification on thermal behaviorand surface roughness, regardless the type of the resin used (heat or self-curing).The same conclusions have been reached by other studies that found that, in low concentrations,AgNPs, have no negative clinical effect on the thermal properties of acrylic resins. Although the glass transition temperature decreased, the relative decline was not significant enough to sacrifice the thermal stability of the denture base resin [29-31].

\section{Conclusions}

The addition of AgNPs to dental resins for antimicrobial activity should be performed in optimal size and concentration, in order to prevent any negative effect on the resin properties. Within the limitation of this study, we can conclude that structure and thermal behavior have not been modified by the chosen particle size and concentration.

\section{References}

1.PICA, A, FICAI, D, GURAN, C, Rev. Chim. (Bucharest), 63, no 5, 2012, p.2459

2.GURAU, G., COMAN, M., DINU, C.A., BUSILA, C., VOICU, D.C., MACOVEI, L.A., CALIN, A.M. The Electrophoretic Patterns of Serum
Proteins in Children., Rev. Chim. (Bucharest), 67, no.1, 2016, p.190194

3.HAN Z, ZHU B, CHEN R, HUANG Z, ZHU C, ZHANG X.,. Mater Des; 65, 2015, p.1245

4.KASSAEE M. Z., AKHAVAN A., SHEIKH N., SODAGAR A., J ournal of Applied Polymer Science, 110, no 3, 2008, p.1699

5.NAM K., Journal of Advanced Prosthodontics, 3, no 1, 2011, p.20 6.CORREA I.M., I MORI M, SANCHES H.L., DA CRUZ A. D., POIATE E. JR., POLA POIATE A.V.Int J Biomater., 48. no 5, 2015, p.275.

7.CALIN, A.M., DEBITA, M., CIURCANU, O.E., SCUTARIU, M.M., SZALONTAY, A.S. Rev. Chim. (Bucharest), 68, no.10, 2017, p. 2443.

8.SCUTARIU MM, HINGANU D, MACOVEI G, HINGANU MV. Romanian Journal Of Oral Rehabilitation, 10, no.4, 2018, p. 186.

9.SODAGAR A., KASSAEE M. Z., AKHAVAN A., JAVADI N., ARAB S, KHARAZIFARD M.J. J ournal of Prosthodontic Research, 56, 2012, p. 120

10.DAR-ODEH NS, SHEHABI AA., Mycoses, 46, no (5-6), 2003, p.187

11.HINGANU, D., HINGANU, M.V., MIHALCEANU, E., CALIN, A.M., PANGAL, A., COSTACHESCU, G., ROMILA, A. Rev. Chim.( Bucharest), 69, no.3, 2018, p. 714.

12.ARBUNE, M., FOTEA, S., NECHITA, A., STEFANESCU, V. JOURNAL OF CRITICAL CARE MEDICINE, 4, no. 3, 2018, p. 96.

13.HINNGANU D, SCUTARIU MM, HINGANU MV. The existence of labial SMAS - Anatomical, imaging and histological study. ANNALS OF ANATOMY-ANATOMISCHER ANZEIGER, 2018, 218, p. 271.

14.GHAFFARI T, HAMEDIRAD F, EZZATI B., J Dent Res resins Dent Clin Dent Prospects., 8, no 4, 2014, p. 204

15.HAMEDI-RAD F, GHAFFARI T, REZAII F, RAMAZANI A., J Dent (Tehran), 11, no 5, 2014, p.495

16.LEE HH, LEE CJ, ASAOKA K.., Dent Mater J ., 31, no 1, 2012, p. 157 17.MACHADO C.,SANCHEZ E., AZER S.S., J Dent., 35, no 12, 2007, p. 930

18.MACOVEI, L.A., CRISTESCU, V., DEBITA, M., et al, Rev. Chim.(Bucharest), 68, no. 10, 2017, p. 2440.

19.ROMANEC, C., PACURAR, M., DECUSARA, M., SCUTARIU, M.M., HINGANU, D., HINGANU, M.V., CIUPILAN, C., Rev Chim. (Bucharest), 69, no. 4, 2018, p. 1002.

20.DEBITA, M., MUSAT, C., MEREUTA, E., et al. Rev Chim. (Bucharest), 68, no.9, 2017, p. 2048.

21.CIURCANU, O.E., MARECI, D., STEFANESCU, O.M., TRINCA, L.C. , SCUTARIU, M.M. , ILIE, M, HRITCU, LD.. Rev Chim, (Bucharest), 67, no.10, 2016, p. 2095. 
22.ROMAN, I., CIORTAN, S., BIRSAN, I.,G., et al. M. Plast., 52, no.4, 2015, p. 529.

23.SCUTARIU, MM, CIURCANU, OE, FORNA, DA et al. MEDICALSURGICAL JOURNAL-REVISTA MEDICO-CHIRURGICALA, 120, no.4, 2016, p. 926.

24.DECUSARA, M., ROMILA, A., PAVEL, L., et al. Rev Chim. (Bucharest), 69, no.5, 2018, p. 1254.

25.HINGANU MV, HINGANU D, COZMA SR, ASIMIONOAIEI-SIMIONESCU

C, SCUTARIU IA, IONESIE DS, HABA D. Annals of Anatomy, 220, 2018, p. 1.
26.DIACONU POPA, D., COMANECI, R., TATARCIUC, M., MURARIU, A., VITALARIU, A.. M., Rev. C him.(Bucharest), 67, no.11, 2016, p.2311. 27.DIACONU POPA D., VITALARIU A., TATARCIUC M., MUNTEANU $F_{\text {., }}$ Rev. Chim.(Bucharest), 67, no. 8, 2016, p.1571.

28.CHLADEK G, KASPERSKI I , BARSZCZEW SKA-RYBAREK I, ZMUDZKI J, IntJ MolSci, 14, 2013, p. 563.

29.KOROGLU A., SAHIN O., KURKCUOGLU I., DEDE D.O., OZDEMYR T., HAZER B., J Appl Oral Sci., 24, no 6, 2 016, p. 590.

30.MARECI D, EARAR K, ZETU I, Mat. Plast., 52, no.2, 2015, p.150 31.ASAFTEI, I.V., SANDU, I.G., BIRSA, L.M, Rev. Chim.(Bucharest), 66, no.3, 2015, p.336.

Manuscript received: 26.07 .2018 